\title{
Impact of Antibacterial Activity of Physical Storage Extracts on Pathogenic Bacteria
}

\author{
Ashwag Al-Zahrani', Hanan Omer², Awatif Al-Judaibi2* \\ ${ }^{1}$ Department of Food Science, Faculty for Girls, King Abdulaziz University, Jeddah, Kingdom of Saudi Arabia \\ ${ }^{2}$ Department of Biological Science, Science Faculty for Girls, King Abdulaziz University, Jeddah, Kingdom of \\ Saudi Arabia \\ Email: "tarawa62@hotmail.com
}

Received 17 March 2016; accepted 19 April 2016; published 22 April 2016

Copyright (C) 2016 by authors and Scientific Research Publishing Inc.

This work is licensed under the Creative Commons Attribution International License (CC BY). http://creativecommons.org/licenses/by/4.0/

(c) (i) Open Access

\section{Abstract}

The overuse of antibiotics can lead to resistance among pathogenic bacteria. A new antibiotic that is effective against new and resistant bacterial strains is needed. Plants and marine organisms may offer such novel treatments. In this study, extracts of the seaweed $U$. lactuca, and the plant seeds $N$. sativa were tested against strains of Gram-positive cocci and Gram-negative bacilli $S$. aureus, and $P$. aeruginosa. The results of the bacterial inhibitor showed high activity in both extracts with inhibition of $S$. aureus growth up to $30 \mathrm{~mm}$ and $20 \mathrm{~mm}$ and $P$. aeruginosa growth inhibition was up to $12 \mathrm{~mm}$ and $15 \mathrm{~mm}$, after the treated with $100 \mu \mathrm{l} U$. lactuca and $N$. sativa extracts, respectively. The MICs and MBCs were reflected with the growth inhibitor with values of $2 \mu \mathrm{l}, 8 \mu \mathrm{l}$ and 4 $\mu \mathrm{l}, 8 \mu \mathrm{l}$ for $S$. aureus and $P$. aeruginosa after treated with $N$. sativa respectively. Kill-time increases as concentrations of $U$. lactuca and $N$. sativa extracts increase. Moreover, extracts stored in the transparent bottle decreased in effectiveness after one month of storage with percentage of $58.85 \%$. After three months, heating the extracts of $U$. lactuca and $N$. sativa to $90^{\circ} \mathrm{C}$ increased their antibacterial activity.

\section{Keywords}

Resistant Bacteria, S. aureus, P. aeruginosa, U. lactuca, N. sativa, Kill-Time

\section{Introduction}

Bacterial infections are usually treated with antibiotics. However, these drugs can be expensive. The continued use of antibiotics can also lead to bacterial resistance and thus decreased efficiency. Antibiotics can also cause

\footnotetext{
${ }^{*}$ Corresponding author.
} 
adverse effects, such as hypersensitivity and depletion of beneficial microbes in the gut [1]. For these reasons, the WHO has suggested the need for alternative treatments [2]. The increased demand for biodiversity in drug development has led to the identification of several compounds that can inhibit pathogenic bacterial growth and may provide new antibiotic medicines.

Marine organisms, especially seaweeds, have a broad range of antibacterial, antifungal, antitumor, and antioxidant behavior. The chemical structures of seaweed include sterols, isoprenoids, amino acids, terpenoids, phlorotannins, steroids, phenolic compounds, fatty acids, and acrylic acid [3]-[5]. Seaweed-based products include alginate, carrageenan, and agar as phycocolloids. These products are abundantly available, renewable, and have been used for decades in medicine and pharmacy [6]. Seaweeds are also known to produce certain bioactive molecules [7]-[10], which interact with other organisms in the environment to inhibit bacterial or fungal growth [6] [11]. Seaweed's antimicrobial activity may also include the ability to synthesize bioactive secondary metabolites [12]-[14]. The extracts and active constituents of various marine seaweeds have been shown to have antibacterial activity against Gram-positive and Gram-negative bacteria [15]-[17].

The use of plant extracts in the treatment of diseases dates back to ancient times, and medicinal plants are widely used in contemporary medicine. Medicinal plants contain active compounds and essential oils. Si et al. [18] studied 66 essential oils and found that nine demonstrated particularly high efficacy against S. typhimurium DT104, E. coli O157: H7, and E. coli with K88 pili and significantly inhibited E. coli and coliform bacteria in the digestive system, with little effect on beneficial lactobacilli and anaerobic bacteria.

The coastlines of Jeddah in Saudi Arabia are abundant resources of many varieties of seaweeds and plant materials used in traditional medicine. The aim of the present study was to screen the effect of heat and storage on the antibacterial activity of Ulva lactuca and Phoenix dactylifera against Staphylococcus aureus, Pseudomonas aeruginosa.

\section{Materials and Methods}

\subsection{Study Bacteria}

Bacteria were isolated and identified at King Abdulaziz University Hospital in Jeddah, Saudi Arabia as Staphylococcus aureus, Pseudomonas aeruginosa, plates were prepared by inoculating $100 \mu^{-1}$ of each sample $(1 \times$ $10^{5}$ colony-forming units) onto Mueller-Hinton agar (OXOID CM 337) was as follows (g/L): beef, 300.00; casein acid hydrolysate 17.50 ; starch 1.50 ; agar 17.00 . The final $\mathrm{pH}$ was $7.3 \pm 0.1$ at $25^{\circ} \mathrm{C}$.

\subsection{Study Materials}

The study materials were the green algae Ulva lactuca which was from Red Sea coastal areas around Jeddah, located between $21^{\circ} \mathrm{N}$ and $39^{\circ} \mathrm{E}$, and the seeds of Nigella sativa and was collected from Jeddah markets. They were washed with distilled water several times, spread on plates and dried at $40^{\circ} \mathrm{C}$. After drying, they were

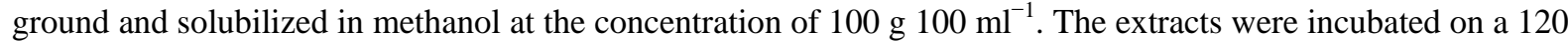
rpm shaker at $30^{\circ} \mathrm{C}$ for $24 \mathrm{~h}$ and then filtered by using Whatman No. 1, after then it had dried under the reduced pressure at $40^{\circ} \mathrm{C}$, and the deposits were used as crude extracts [19].

\subsection{Antibacterial Assays}

Each crude extract was determined in vitro against the methicillin resistant S. aureus and P. aeruginosa. The activity of each extract was measured by the disc diffusion method following Clinical and Laboratory Standards Institute protocols [20]. Each extract was dissolved in dimethylsulfoxide (DMSO) with $3 \mu \mathrm{g} \cdot \mathrm{ml}^{-1}$ and filtered by a $0.22 \mu \mathrm{m}$ filter (Millipore, Billerica, MA). $100 \mu \mathrm{l}$ of each solution were placed on $1 \mathrm{~mm}$ paper discs. Negative control was prepared with the solvent, and Augmentin XR $(1 \mathrm{mg} / \mathrm{ml})$ was used as the positive control. After inoculation, plates were incubated at $37^{\circ} \mathrm{C}$ for $24 \mathrm{~h}$ and the inhibition zones were measured. All tests were performed in triplicate.

The extracts that inhibited the bacterial growth were tested to determine the minimum inhibitory concentrations (MICs) using serially diluted with Mueller-Hinton broth in a 96-well microplate [21]. Bacteria were cultured overnight on Mueller-Hinton agar and then suspended in $1 \mathrm{ml}^{-1}$ of Mueller-Hinton broth (OXOID CM 405) to give a final concentration of $5 \times 10^{5}$ colony-forming units $\mathrm{ml}^{-1}$. The microplate were inoculated with the bacteria and incubated at $37^{\circ} \mathrm{C}$ for $16-20 \mathrm{~h}$, and were evaluated for the visible presence or absence of bacterial growth. MICs were determined as the lowest concentration of an extract for which there was no visible growth 
compared to the control [22].

The minimum bactericidal concentrations (MBCs) were determined by inoculating $0.1 \mathrm{ml}$ of the negative growth wells in the MICs assays onto nutrient agar. Plates were incubated at $37^{\circ} \mathrm{C}$ for $24 \mathrm{~h}$. MBCs were considered to be the concentration that showed no growth of the tested bacteria, negative control was a plate that contained only medium [23]-[25].

\subsection{Kill-Time Determination}

This experiment was assayed to estimate the rate of killing bacteria by the crude methanol extract. Using the method of [26], the extract was incorporated into $10 \mathrm{ml}$ Mueller Hinton broth in McCartney bottles at $1 / 2 \times$ MIC, $1 \times$ MIC, and $2 \times$ MIC. Two controls, a Mueller-Hinton broth without extract inoculated with test organisms and a Mueller-Hinton broth incorporated with the extract at the test concentrations without the test organisms, were included. Inoculums density, approximately $10^{5} \mathrm{cfu} / \mathrm{ml}$ further verified by total viable count, was used to inoculate $10 \mathrm{ml}$ volumes of both in the McCartney bottles and control bottles. The bottles were incubated at $37^{\circ} \mathrm{C}$. A $100-\mu \mathrm{l}$ aliquot was removed from the culture medium at $0,2,4,8,12$, and $24 \mathrm{~h}$ to determine cfu/ml by using the Standard Plate Count technique [27]. After incubating at $37^{\circ} \mathrm{C}$ for $24 \mathrm{~h}$, the visible colonies were read by using an Interscience scan of 500 colony counters. Bacterial colonies were counted as cfu/ml and compared with the control count [28] [29]. Each treatment was performed in triplicate.

\subsection{Effect of Storage on U. lactuca and N. sativa Methanol Extracts}

To investigate the effect of storage time and the type of storage material on antibacterial activity of $U$. lactuca and $N$. sativa, extracts were divided into two major groups. In the first group, the extracts were stored in sterilized dark bottles. In the second group, the extracts were stored in sterilized transparent bottles. Each group was further subdivided into three portions that were stored for 1, 2, and 3 months before laboratory analyses. The positive control was crude of $U$. lactuca and $N$. sativa at $4^{\circ} \mathrm{C}$. Overnight nutrient broth cultures of $S$. aureus and $P$. aeruginosa. The cells were then suspended to the concentration of $5 \times 10^{5}$ colony-forming units $\mathrm{ml}^{-1}$. By using holes in the agar, $100 \mu \mathrm{l}$ of $S$. aureus or $P$. aeruginosa were inoculated in the plates, $100 \mu \mathrm{l}$ of storage-treated extracts were added to the hole, and then the cultures were incubated at $30^{\circ} \mathrm{C}$ for $24 \mathrm{~h}$. Three replicates of each treatment were done. Results were recorded by measuring the diameter of the inhibition zone [30].

\subsection{Effect of Temperatures on U. lactuca and N. sativa Methanol Extracts}

This study evaluates the effect of several temperature treatments on the antibacterial activity of the U. lactuca and $N$. sativa methanol extracts, Both $U$. lactuca and $N$. sativa were tested for their antibacterial activity after treated with $-80^{\circ} \mathrm{C}, 5^{\circ} \mathrm{C}, 22^{\circ} \mathrm{C}, 50^{\circ} \mathrm{C}$, and $90^{\circ} \mathrm{C}$. Overnight nutrient broth cultures of $S$. aureus and P. aeruginosa were centrifuged, and the cells were washed three times with sterilized deionized water. The cells were then suspended in a concentration of $5 \times 10^{5}$ colony-forming units $\mathrm{ml}^{-1}$. Using holes in the agar, $100 \mu \mathrm{l}$ of $S$. aureus or $P$. aeruginosa were inoculated in the plates, $100 \mu \mathrm{l}$ of temperature-treated extracts were added to the hole, and then were incubated at $30^{\circ} \mathrm{C}$ for $24 \mathrm{~h}$. Three replicates of each treatment were done. Results were recorded by measuring the diameter of the inhibition zone [30].

\subsection{Statistical Analysis}

Results were analyzed by paired-samples $t$-test using the IBM SPSS 20 statistical software to compare the mean values of each treatment, and they are expressed as means \pm SE. Probability levels of less than 0.01 were considered highly significant.

\section{Results}

In this study, the effect of the ethanol extracts of $U$. lactuca and $N$. sativa was estimated by the inhibition of the bacterial growth and the determination of MICs and MBCs. The MICs concentrations of the algae and plant extracts were then assayed to determine the ability of the extracts activity after storage and temperatures treatments. The results in Table 1 showed the effect of $U$. lactuca and $N$. sativa ethanol extracts on the growth inhibition with the concentrations of 30,50,100, 150 and $200 \mathrm{mg} / \mathrm{ml}$, S. aureus was sensitive to all the concentrations and 
Table 1. Inhibition of bacterial growth (mm) after 24 hours of treated with $100 \mu \mathrm{U}$. lactuca and $N$. sativa methanol extracts (Mean \pm SD).

\begin{tabular}{cccccccccccc}
\hline \multicolumn{1}{c}{ U. lactuca } & & & N. sativa & Augmentin XR \\
\hline Bacteria & $30 \mathrm{mg} / \mathrm{ml}$ & $50 \mathrm{mg} / \mathrm{ml}$ & $100 \mathrm{mg} / \mathrm{ml}$ & $150 \mathrm{mg} / \mathrm{ml}$ & $200 \mathrm{mg} / \mathrm{ml}$ & $30 \mathrm{mg} / \mathrm{ml}$ & $50 \mathrm{mg} / \mathrm{ml}$ & $100 \mathrm{mg} / \mathrm{ml}$ & $150 \mathrm{mg} / \mathrm{ml}$ & $200 \mathrm{mg} / \mathrm{ml}$ & $200 \mathrm{mg} / \mathrm{ml}$ \\
S. aureus & $25 \pm 1.527^{* *}$ & $28 \pm 1.000^{* *}$ & $30 \pm 1.155^{* *}$ & $30 \pm 1.000^{* *}$ & $32 \pm 4.000^{* *}$ & $14 \pm 2.517^{*}$ & $15 \pm 1.000^{* *}$ & $20 \pm 2.000^{* *}$ & $14 \pm 1.732^{* *}$ & $16 \pm 3000^{*}$ & $12 \pm 0.135^{* *}$ \\
P. aeruginosa & 0 & $9 \pm 1.527^{*}$ & $12 \pm 1.000^{* *}$ & $12 \pm 1.000^{* *}$ & $13 \pm 4.000$ & 0 & $14 \pm 1.000^{* *}$ & $15 \pm 0.577^{* *}$ & $14 \pm 2.000^{* *}$ & $15 \pm 1.528^{* *}$ & $17 \pm 0.017^{* *}$ \\
\hline
\end{tabular}

${ }^{* *} \mathrm{P} \leq 0.01$.

Table 2. MIC and MBC ( $\mu \mathrm{l} / \mathrm{m})$ of bacterial growth after incubation with $U$. lactuca and $N$. sativa methanol extracts.

\begin{tabular}{ccccc}
\hline & MIC & \multicolumn{2}{c}{ MBC } \\
\hline S. aureus & U. lactuca & N. sativa & U. lactuca & N. sativa \\
P. aeruginosa & 4 & 2 & $>32$ & 8 \\
\hline
\end{tabular}

the $100 \mu$ l were the best concentration with inhibition zone of $30 \mathrm{~mm}$ and $20 \mathrm{~mm}$ after the treated with the extract of $U$. lactuca and $N$. sativa respectively. Increasing the concentrations of the extracts to $150 \mathrm{mg} / \mathrm{ml}$ and 200 $\mathrm{mg} / \mathrm{ml}$ resulted approximate effect with the concentration $100 \mathrm{mg} / \mathrm{ml}$ with inhibitions of $30 \mathrm{~mm}, 32 \mathrm{~mm}$ by the treated with $U$. lactuca, while the extract of $N$. sativa showed a different result in decreased of inhibition effect to $14 \mathrm{~mm}$ and $16 \mathrm{~mm}$ after treated with $150 \mathrm{mg} / \mathrm{ml}$ and $200 \mathrm{mg} / \mathrm{ml}$ respectively.

On other hand, P. aeruginosa showed more resistance than S. aureus, the concentration $30 \mathrm{mg} / \mathrm{ml}$ has no inhibitory effect. While the inhibition at the concentrations of 50, 100, 150 and $200 \mathrm{mg} / \mathrm{ml}$ were approximate with the average of $12 \mathrm{~mm}$ and $15 \mathrm{~mm}$ after the treated with $U$. lactuca and $N$. sativa respectively.

The growth inhibition reflected on the MICs and MBCs and the results shows in Table 2. The extract of $N$. sativa was more effective on the tested bacteria with MIC and MBC of $2 \mu \mathrm{l}, 8 \mu \mathrm{l}$ and $4 \mu \mathrm{l}, 8 \mu \mathrm{l}$ for S. aureus and $P$. aeruginosa respectively.

Table 3 shows the antibacterial activity of $1 / 2,1$, and 2 MIC concentrations of $U$. lactuca and $N$. sativa extracts on bacterial vitality during incubation. The cells were counted after $0,2,4,8,12$, and $24 \mathrm{~h}$. The results of $P$. aeruginosa showed different cell decreases after incubation with $U$. lactuca and $N$. sativa, with percentage of cells vitalities up to $48.04 \%, 74.02 \%, 9.22 \%$, and $66.75 \%$ after incubation with $1 \times$ MIC of $U$. lactuca and $N$. sativa extracts for 2 and $4 \mathrm{~h}$, respectively. The $2 \times$ MIC concentration decreased cell vitality to $44.32 \%$ and $72.78 \%$ after incubation with $U$. lactuca extract for 2 and $4 \mathrm{~h}$. Incubation with $N$. sativa extract decreased cell vitality to $31.07 \%$ after $2 \mathrm{~h}$. The number of vital cells of $S$. aureus decreased at the concentration of $1 / 2 \times$ MIC to $2.10 \%$, $31.36 \%$, and $65.30 \%$, respectively, after 2,4 , and $8 \mathrm{~h}$ of incubation with $U$. lactuca extract. The decreasing percentages of cells incubated with $N$. sativa were $1.89 \%$, $21.79 \%$, and $76.33 \%$, respectively.

The results in Table 4 and Figure 1 show the effect of storage conditions; a transparent and dark storage bottle, on the activity of $U$. lactuca and $N$. sativa extracts against $S$. aureus and $P$. aeruginosa. Extracts stored in the transparent bottle decreased in effectiveness after one month of storage with percentage of $58.85 \%$. After three months, the inhibition of the bacterial growth decreased to $38.90 \%$. Further, after one month of storage, growth inhibition decreased after treated with $N$. sativa to $33.33 \%$.

Extracts stored in the dark bottles performed better. S. aureus growth was inhibited to $53.70 \%$, after stored for one month. While after three months, the growth inhibitor decreased to the percentage $46.30 \%$ by $U$. lactuca treatment.

As shown in Table 5, heating the extracts of $U$. lactuca and $N$. sativa to $90^{\circ} \mathrm{C}$ increased their antibacterial activity. $U$. lactuca and $N$. sativa extracts stored at $-08^{\circ} \mathrm{C}$ decreased the growth of $S$. aureus and P. aeruginosa. $U$. lactuca and $N$. sativa extracts stored in transparent bottles for three months decreased the growth of $S$. aureus. Dark bottles reduced the percentage inhibitory of stored extracts for less than $10 \%$ in the U. lactuca extract and $20 \%$ in the $N$. sativa extract.

\section{Discussion}

The overuse of prescribed antibiotics can lead to resistance among these pathogenic bacteria. Thus, new antibiotics that are effective against new and resistant bacterial strains are needed. Plants and marine organisms may 


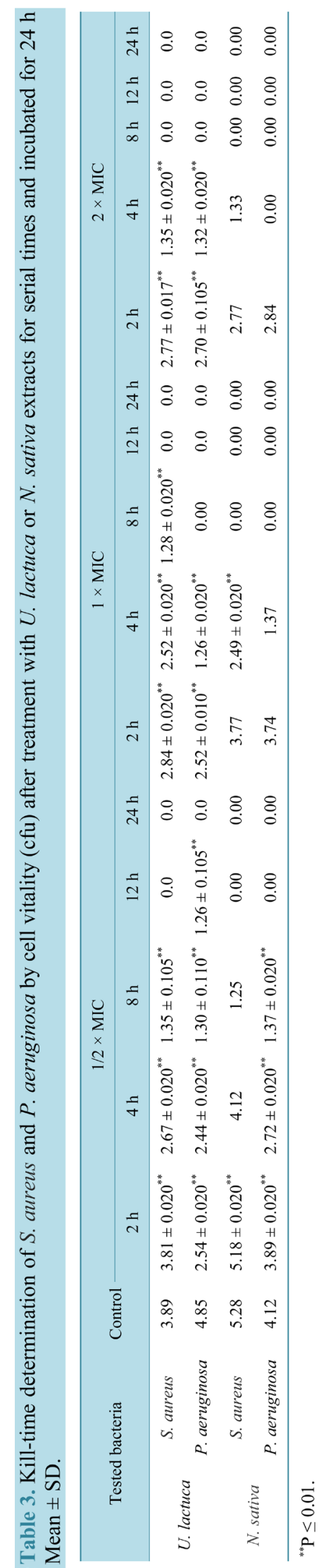


Table 4. Inhibition of bacterial growth (mm) after $24 \mathrm{~h}$ of incubation with $100 \mu \mathrm{l}$ of $U$. lactuca or $N$. sativa extract stored for one, two and three months in two types of storage bottles Mean \pm SD.

\begin{tabular}{|c|c|c|c|c|c|c|c|}
\hline \multirow{2}{*}{\multicolumn{2}{|c|}{$\begin{array}{l}\text { Storage periods } \\
\text { Type of bottles }\end{array}$}} & \multicolumn{2}{|c|}{ One month } & \multicolumn{2}{|c|}{ Two months } & \multicolumn{2}{|c|}{ Three months } \\
\hline & & Transparent bottles & Dark bottles & Transparent bottles & Dark bottles & Transparent bottles & Dark bottles \\
\hline \multirow{2}{*}{ U. lactuca } & S. aureus & $28 \pm 0.096^{* *}$ & $29 \pm 0.096^{* *}$ & $27 \pm 0.096^{* *}$ & $28 \pm 0.096^{* *}$ & $21 \pm 0.096^{* *}$ & $25 \pm 0.096^{* * *}$ \\
\hline & P. aeruginosa & $28 \pm 0.096^{* *}$ & $30 \pm 0.096^{* *}$ & $32 \pm 0.096^{* *}$ & $35 \pm 0.096^{* *}$ & $36 \pm 0.096^{* *}$ & $37 \pm 0.096^{* * *}$ \\
\hline \multirow{2}{*}{ N. sativa } & S. aureus & $18 \pm 0.115^{* *}$ & $19 \pm 0.096^{* *}$ & $13 \pm 0.096^{* *}$ & $15 \pm 0.115^{* *}$ & $12 \pm 0.115^{* *}$ & $13 \pm 0.096^{*+}$ \\
\hline & P. aeruginosa & $23 \pm 0.096^{* *}$ & $25 \pm 0.096^{* *}$ & $27 \pm 0.096^{* *}$ & $30 \pm 0.096^{* *}$ & $32 \pm 0.096^{* *}$ & $32 \pm 0.096^{* *}$ \\
\hline
\end{tabular}

${ }^{* * *} \mathrm{P} \leq 0.01$.

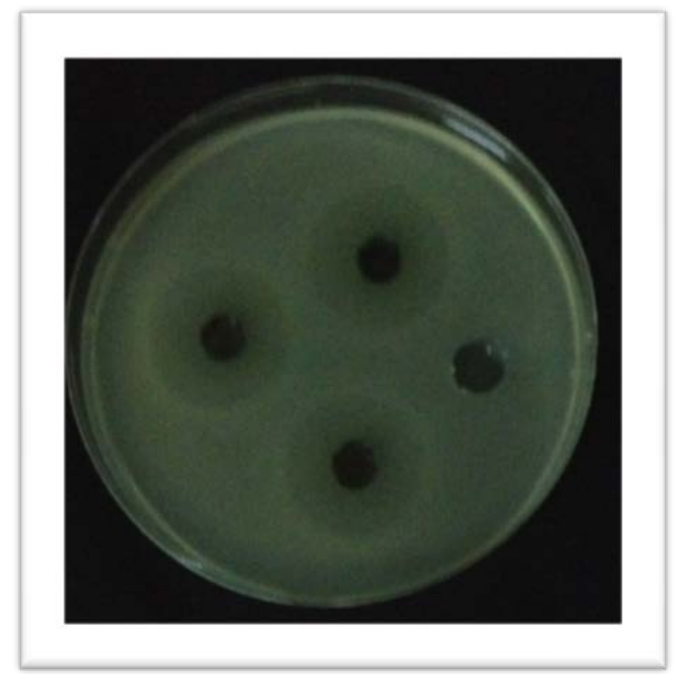

S. aureus treated with $U$. lactuca extract and stored for three month in transparent bottles

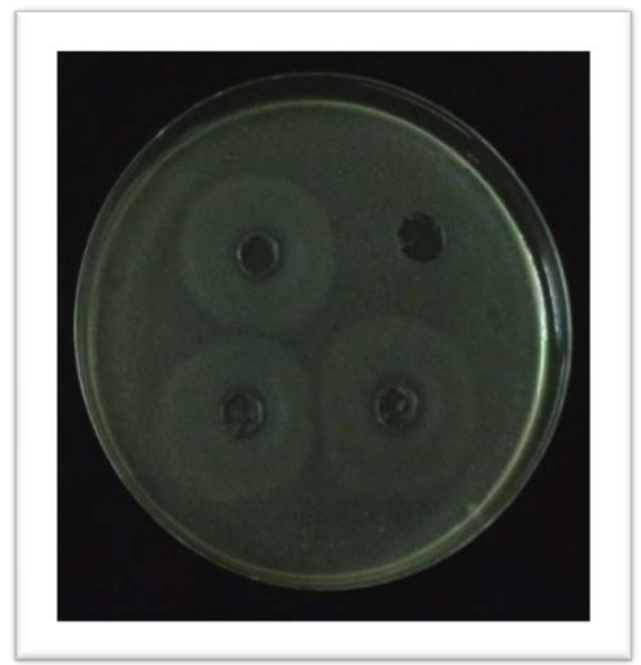

$P$. aeruginosa treated with $N$. sativa and stored for three months in transparent bottles

Figure 1. Bacterial inhibition growth after 24 h of incubation with $U$. lactuca or $N$. sativa extracts and stored for three months in transparent storage bottles.

offer such novel treatments. To that end, extracts of the seaweed U. lactuca, and the plant P. dectylefera were tested against strains of Gram-positive cocci and Gram-negative bacilli S. aureus, and P. aeruginosa. Seaweed metabolism is influenced by extreme marine environmental conditions, including high pressure, temperature, and osmolarity, as found in our study sites, Red Sea coastal areas in Jeddah. It is also affected by the presence of 
Table 5. Inhibition of bacterial growth (mm) after $24 \mathrm{~h}$ of incubation with $100 \mu \mathrm{l}$ of $U$. lactuca or $N$. sativa extract treated with serial temperatures Mean \pm SD.

\begin{tabular}{|c|c|c|c|c|c|c|}
\hline \multicolumn{2}{|c|}{ Temperatures } & \multirow{2}{*}{$\begin{array}{c}90^{\circ} \mathrm{C} \\
30 \pm 0.096^{* *}\end{array}$} & \multirow{2}{*}{$\frac{50^{\circ} \mathrm{C}}{28 \pm 0.096^{* *}}$} & \multirow{2}{*}{$\frac{22^{\circ} \mathrm{C}}{27 \pm 0.096^{* *}}$} & \multirow{2}{*}{$\frac{5^{\circ} \mathrm{C}}{23 \pm 0.096^{* *}}$} & \multirow{2}{*}{$\frac{-80^{\circ} \mathrm{C}}{20 \pm 0.135^{* *}}$} \\
\hline & S. aureus & & & & & \\
\hline U. lactuca & P. aeruginosa & $13 \pm 0.096^{* *}$ & $13 \pm 0.096^{* *}$ & $12 \pm 0.115^{* *}$ & $12 \pm 0.115^{* *}$ & $11 \pm 0.096^{* *}$ \\
\hline \multirow{2}{*}{ N. sativa } & S. aureus & $22 \pm 0.135^{* *}$ & $20 \pm 0.135^{* *}$ & $20 \pm 0.135^{* *}$ & $19 \pm 0.096^{* *}$ & $17 \pm 0.096^{* *}$ \\
\hline & P. aeruginosa & $17 \pm 0.096^{* *}$ & $16 \pm 0.135^{* *}$ & $16 \pm 0.135^{* *}$ & $16 \pm 0.135^{* *}$ & $15 \pm 0.115^{* *}$ \\
\hline
\end{tabular}

${ }^{* * *} \mathrm{P} \leq 0.01$.

organic compounds, such as isonitrile, dichloramine, isocyanate, and halogenated compounds [31]. Bioactive compounds in antibacterial agents inhibit bacterial growth. These compounds include secondary metabolism components, such as alkaloids, peptides, terpenes, pigments, and sterols [32].

A study of antimicrobial activity of seaweeds $U$. reticulata and $U$. lactuca extracts showed promising antimicrobial activity against bacterial and fungal human pathogens [33]. In addition, $P$. mirabilis and $E$. coli were sensitive to the methanolic extract of $U$. lactuca, and $S$. aureus and $P$. aeruginosa were resistant to $U$. lactuca [34]. Selvin and Lipton [35] reported that the green alga $U$. fasciata exhibited broad spectrum antibacterial activity, these results agree with our results on $U$. lactuca. $U$. fasciata showed a broad spectrum of antibacterial activity, inhibiting the growth of both Gram-positive and Gram-negative tested organisms.

The effect of the bacterial inhibition growth reflected on the concentrations of both extracts's MICs and MBCs. MICs and MBCs were detected from methanol extract of Stachytarpheta indica, Ligaria cuneifolia and Jodina rhombifolia, and the MICs and MBCs were comparable to the results in this study [36] [37].

Kill-time is the time it takes for cells to recover after incubation with an antimicrobial agent. Kill-time increases as concentrations of $U$. lactuca and $N$. sativa extracts increase. This is likely due to the increase in bioactive compounds that exist in the extracts.

The ideal antibiotic should remain stable during extended storage periods and temperature fluctuations. $U$. lactuca and $N$. sativa extracts maintained high antibacterial activity against $S$. aureus and $P$. aeruginosa after three months of storage at $90^{\circ} \mathrm{C}$. This robustness may due to the concentrated and stability of its bioactive compounds. Other study results are consistent with ours [38]-[41]. Moreover, using dark bottles to store the extracts resulted in higher antibacterial activity, compared with the transparent bottles, this may due to biochemical light oxidation in the transparent bottles [42] [43].

\section{Conclusion}

The overuse of antibiotics can lead to resistance of pathogenic bacteria. A new antibiotic that is effective against new and resistant bacterial strains is needed. Medicinal plants and marine algae may offer such novel treatments. In this study, extracts of $U$. lactuca, and $N$. sativa were tested against $S$. aureus, and $P$. aeruginosa. The results of the bacterial inhibitor showed high activity in both extracts against $S$. aureus and $P$. aeruginosa. The MICs and MBCs were reflected with the growth inhibitor. Kill-time increases as concentrations of $U$. lactuca and $N$. sativa extracts increase. Moreover, extracts stored in the transparent bottle decreased in effectiveness after three months, and heating the extracts of $U$. lactuca and $N$. sativa to $90^{\circ} \mathrm{C}$ increased their antibacterial activity.

\section{References}

[1] Badea, V., Balaban, D.P., Rapeanu, G., Amariei, C. and Badea, C.F. (2009) The Antibacterial Activity Evaluation of Cystoseira barbata Biomass and Some Alginates upon Bacteria from Oropharyngeal Cavity. Romanian Biotechnological Letters, 14, 4851-4857.

[2] Abdul Hannan, S., Chaudhary, S., Barkaat, M. and Arshad, M. (2008) Anti Bacterial Activity of Nigella sativa against Clinical Isolates of Methicillin Resistant Staphylococcus aureus. Journal of Ayub Medical College Abbottabad, 20, 72 74.

[3] Ahmad, V.U., Aliya, R., Perveen, S. and Shameel, M. (1993) Sterols from Marine Green Alga Codium decorticatum. Phytochemistry, 33, 1189-1192. http://dx.doi.org/10.1016/0031-9422(93)85047-U

[4] Taskin, E., Ozturuk, M. and Kurt, O. (2001) Turkiye’nin yararlanilabilir denizel alg potansiyeli. XI. Ulusal Su Urunleri Sempozyumu, 225-232. http://dx.doi.org/10.3923/jas.2010.3007.3013 
[5] Nor Afifah, S., Darah, I., Shaida Far, S., Jain Nordi, M.K. and Nurul Aili, Z. (2010) Antimicrobial Activity of Various Extracts of a Tropical Chlorophyta macroalgae, Halimeda discoidea. Journal of Applied Sciences, 10, 3007-3013.

[6] Singh, A. and Chaudhary, B. (2010) Preliminary Phycochemical Analysis and in Vitro Antibacterial Screening of Pithophora oedogonia (Mont.) Wittrock: A Fresh Water Green Alga Forming Mats in the Water Bodies. Journal of Algal Biomass Utilization, 1, 33-41.

[7] Yuan, Y.V. and Walsh, N.A. (2006) Antioxidant and Antiproliferative Activities of Extracts from a Variety of Edible Seaweeds. Food and Chemical Toxicology, 44, 1144-1150. http://dx.doi.org/10.1016/j.fct.2006.02.002

[8] Thirumaran, G., Vijayabaskar, P. and Anantharaman, P. (2006) Antibacterial and Antifungal Activities of Brown Marine Macro Alaga Dictyota dichotoma from the Gulf of Mannar Biosphere Reserve. Environ. Ecol, 24, 37-40.

[9] Vairappan, C.S., Ishii, T., Lee, T.K., Suzuki, M. and Zhaoqi, Z. (2010) Antibacterial Activities of a New Brominated Diterpene from Borneon Laurencia spp. Marine Drugs, 8, 1743-1749. http://dx.doi.org/10.3390/md8061743

[10] Zbakh, H., Chiheb, H., Bouziane, H., Sanchez, V.M. and Riadi, H. (2012) Antibacterial Activity of Benthic Marine Algae Extracts from the Mediterranean Coast of Morocco. Journal of Microbiology, Biotechnology and Food Sciences, 2, 219-228.

[11] Pushpamali, W.A., Nikapitiya, C., De Zoysa, M., Whang, I., Kim, S.J. and Lee, J. (2008) Isolation and Purification of an Anticoagulant from Fermented Red Seaweed Lomentaria catenata. Carbohydrate Polymers, 73, 274-279. http://dx.doi.org/10.1016/j.carbpol.2007.11.029

[12] Siddhanta, A.K., Mody, K.H., Ramavat, B.K., Chauhan, V.D., Garg, H.S., Goel, A.K., Doss, M.J., Srivastava, M.N., Patnaik, G.K. and Kamboj, V.P. (1997) Bioactivity of Marine Organisms: Part VIII-Screening of Some Marine flora of Western Coast of India. Indian Journal of Experimental Biology, 35, 638-643.

[13] Villarreal-Gómez, L.J., Soria-Mercado, I.E., Guerra-Rivas, G. and Ayala-Sánchez, N.E. (2010) Antibacterial and Anticancer Activity of Seaweeds and Bacteria Associated with Their Surface. Revista de Biology Marinay Oceanografa, 45, 267-275. http://dx.doi.org/10.4067/s0718-19572010000200008

[14] Vijayabaskar, P. and Shiyamala, V. (2011) Antibacterial Activities of Brown Marine Algae (Sargassum wightii and Turbinaria ornata) from the Gulf of Mannar Biosphere Reserve. Advances in Biological Research, 5, 99-102.

[15] Lima-Filho, J.V.M., Carvalho, A.F.F.U., Freitas, S.M. and Melo, V.N.M.M. (2002) Antibacterial Activity of Extracts of Six Macroalgae from the Northeastern Brazilian Coast. Brazilian Journal of Microbiology, 33, 311-314. http://dx.doi.org/10.1590/S1517-83822002000400006

[16] Paul, G., Yusuf, S. and Sharma, S. (2006) Unmasking of the Brugada Syndrome Phenotype during the Acute Phase of Amiodarone Infusion. Circulation, 114, e489-e491. http://dx.doi.org/10.1161/CIRCULATIONAHA.106.620799

[17] Devi, G.K., Manivannan, K., Thirumaran, G., Rajathi, F.A.A. and Anantharaman, P. (2011) In Vitro Antioxidant Activities of Selected Seaweeds from Southeast Coast of India. Asian Pacific Journal of Tropical Medicine, 4, 205-211. http://dx.doi.org/10.1016/S1995-7645(11)60070-9

[18] Si, W., Gong, J., Tsao, R., Zhou, T., Yu, H., Poppe, C., Johnson, R. and Du, Z. (2006) Antimicrobial Activity of Essential Oils and Structurally Related Synthetic Food Additives towards Selected Pathogenic and Beneficial Gut Bacteria. Journal of Applied Microbiology, 100, 296-305. http://dx.doi.org/10.1111/j.1365-2672.2005.02789.x

[19] Vijayakumar, M., Priya, K., Nancy, F.T., Noorlidah, A. and Ahmed, A.B.A. (2013) Biosynthesis, Characterisation and Antibacterial Effect of Plantmediated Silver Nanoparticles Using Artemisia nilagirica. Indust. Crops Products, 41, 235-240. http://dx.doi.org/10.1016/j.indcrop.2012.04.017

[20] Wikler, M.A. (2007) Performance Standards for Antimicrobial Susceptibility Testing: Seventeenth Informational Supplement. Clinical and Laboratory Standards Institute (CLSI), Wayne.

[21] CLSI (2012) Performance Standards for Antimicrobial Disk Susceptibility Tests; Approved Standard—Eleventh Edition. CLSI Document M02-A11. Vol. 32, Clinical and Laboratory Standards Institute, Wayne.

[22] CLSI (2007) Performance Standards for Antimicrobial Susceptibility Testing; Seventeenth Information Supplement. CLSI Document M100-S17 (M2-A7 and M7-A7). Vol. 27, Clinical and Laboratory Standards Institute, Wayne.

[23] Wiegand, I., Hilpert, K. and Hancock, R.E.W. (2008) Agar and Broth Dilution Methods to Determine the Minimal Inhibitory Concentration (MIC) of Antimicrobial Substances. Nature Protocols, 3, 163-175. http://dx.doi.org/10.1038/nprot.2007.521

[24] Hernandes, C., Coppede, J.D.S., Bertoni, B.W., França, S.D.C. and Pereira, A.M.S. (2013) Flash Microbiocide: A Rapid and Economic Method for Determination of MBC and MFC. American Journal of Plant Sciences, 4, 850-852. http://dx.doi.org/10.4236/ajps.2013.44104

[25] Joshua, M. and Takudzwa, M. (2013) Antibacterial Properties of Mangifera Indica on Staphylococcus aureus. African Journal of Clinical and Experimental Microbiology, 14, 62-74.

[26] Madigan, M.T., Martinko, J.M. and Parker, J. (1997) Brock Biology of Microorganisms. 8th Edition, Prentice Hall In- 
ternational, Inc., New York.

[27] Rocha-Martin, J., Harrington, C., Dobson, A.D.W. and Ogara, F. (2014) Emerging Strategies and Integrated Systems Microbiology Technologies for Biodiscovery of Marine Bioactive Compounds. Marine Drugs, 12, 3516-3559. http://dx.doi.org/10.3390/md12063516

[28] Wu, D. and Sun, D.W. (2013) Potential of Time Series-Hyperspectral Imaging (TS-HSI) for Non-Invasive Determination of Microbial Spoilage of Salmon Flesh. Talanta, 111, 39-46. http://dx.doi.org/10.1016/j.talanta.2013.03.041

[29] Barbosa, M., Valentao, P. and Andrade, P.B. (2014) Bioactive Compounds from Macroalgae in the New Millennium: Implications for Neurodegenerative Diseases. Marine Drugs, 12, 4934-4972. http://dx.doi.org/10.3390/md12094934

[30] Al-Awadi, A. and Al-Judaibi, A. (2014) Effects of Heating and Storage on the Antifungal Activity of Camel Urine. Clinical Microbiology, 3, 179.

[31] Kolanjinathan, K. and Stella, D. (2011) Pharmacological Effect of Gracilaria corticata Solvent Extracts against Human Pathogenic Bacteria and Fungi. International Journal of Pharmaceutical \& Biological Archive, 2, 1722-1728.

[32] Pushparaj, A., Raubbin, R.S. and Balasankar, T. (2014) Antibacterial Activity of Kappaphycus alvarezii and Ulva lactuca Extracts against Human Pathogenic Bacteria. International Journal of Current Microbiology and Applied Sciences, 3, $432-436$.

[33] Christabell, J., Lipton, A.P., Aishwarya, M.S., Sarika, A.R. and Udayakumar, A. (2011) Antibacterial Activity of Aqueous Extract from Selected Macroalgae of Southwest Coast of India. Seaweed Research Utilization, 33, 67-75.

[34] Chandrasekaran, M., Venkatesalu, V. and Raj, G.A. (2014) Antibacterial Activity of Selected Marine Macro Algae against Vancomycin Resistant Enterococcus faecalis. Journal of Coastal Life Medicine, 2, 940-946.

[35] Selvin, J. and Lipton, A.P. (2004) Biopotentials of Ulva fasciata and Hypnea musciformis Collected from the Peninsular Coast of India. Journal of Marine Science and Technology, 12, 1-6.

[36] Amenu, D. (2014) Antimicrobial Resistance for Enteric Pathogens Isolated from Acute Gastroenteritis Patients. World Journal of Natural and Applied Sciences, 1, 1-14.

[37] Soberón, J.R., Sgariglia, M.A., Dip Maderuelo, M.R., Andina, M.L., Sampietro, D.A. and Vattuone, M.A. (2014) Antibacterial Activities of Ligaria cuneifolia and Jodina rhombifolia Leaf Extracts against Phytopathogenic and Clinical Bacteria. Journal of Bioscience and Bioengineering, 118, 599-605. http://dx.doi.org/10.1016/j.jbiosc.2014.04.018

[38] Bukvicki, D., Gottardi, D., Tyagi, A.K., Veljic, M., Marin, P.D., Vujisic, L., Guerzoni, M.E. and Vannini, L. (2014) Scapania nemorea Liverwort Extracts: Investigation on Volatile Compounds, in Vitro Antimicrobial Activity and Control of Saccharomyces cerevisiae in Fruit Juice. LWT-Food Science and Technology, 55, 452-458. http://dx.doi.org/10.1016/j.lwt.2013.09.029

[39] Ocheng, F., Bwanga, F., Joloba, M., Borg-Karlson, A.-K., Gustafsson, A. and Obua, C. (2014) Antibacterial Activities of Extracts from Ugandan Medicinal Plants Used for Oral Care. Journal of Ethnopharmacology, 155, 852-855. http://dx.doi.org/10.1016/j.jep.2014.06.027

[40] Friedman, M., Henika, P.R. and Levin, C.E. (2015) Antimicrobial Activities of Red Wine-Based Formulations Containing Plant Extracts against Escherichia coli O157:H7 and Salmonella enterica Serovar Hadar. Food Control, 50, 652-658. http://dx.doi.org/10.1016/j.foodcont.2014.10.005

[41] Adegbolagun, O.M. and Olukemi, O.O. (2010) Effect of Light Irradiation on the Antimicrobial Activity of Zanthoxylum zanthoxyloides (lam) Methanolic Extract. African Journal of Pharmacy and Pharmacology, 4, 145-150.

[42] Akhtar, M.S., Bashir, S. and Sial, N.T. (2012) Antimicrobial Screening of Heterophragma adenophyllum Extracts and Effects of Light Irradiation. Canadian Journal of Applied Sciences, 3, 304-313.

[43] Tanaka, K., Ohgo, Y., Katayanagi, Y., Yasui, K., Hiramoto, S., Ikemoto, H., Nakata, Y., Miyoshi, N., Isemura, M. and Ohashi, N. (2014) Anti-Inflammatory Effects of Green Soybean Extract Irradiated with Visible Light. Scientific Reports, 4, Article No. 4732. http://dx.doi.org/10.1038/srep04732 